\title{
UPPER HOLOCENE DEVELOPMENT OF VEGETATION AND RADIOCARBON DATING IN THE VICINITY OF THE CERHOVKA BROOK (BOHEMIAN-MORAVIAN UPLANDS, CZECH REPUBLIC)
}

\author{
EVA BŘÍZOVÁ ${ }^{1}$, ANNA PAZDUR ${ }^{2}$ and NATALIA PIOTROWSKA ${ }^{2}$ \\ ${ }^{1}$ Czech Geological Survey, Klárov 3/131, 11821 Prague 1, Czech Republic \\ ${ }^{2}$ Silesian University of Technology, Institute of Physics, Department of Radioisotopes, GADAM Centre of Excellence, \\ Krzywoustego 2, 44-100 Gliwice, Poland
}

Received 10 October 2011

Accepted 20 June 2012

\begin{abstract}
The paper reports the results of a palynological study of a newly exposed section in the peat sediments of Bezděkov site and its correlation with the previous palaeobotanical studies. The main goal was to elucidate the stratigraphic position and paleogeographic development of fossil peat bog and its environment in the Protected Landscape Area Žd'árské vrchy and Železné hory in the Bohemian-Moravian Uplands. The development of peatbog vegetation, as shown by the pollen analysis and radiocarbon dating, took place in the Holocene. Pollen analyses provide evidence for occurrences of wetland assemblages with huge representation of alder wood in all the part of succession, followed by willow near the Cerhovka Brook. Alnus and Abies were the dominant trees during all the time. The deciduous forests consist of elm (Ulmus), oak (Quercus), lime tree (Tilia), maple (Acer) and hazel (Corylus). The mosaic picture of woodland and wetland, which covered this landscape during the Upper Holocene, contrasts with the present day monotonous open lowland. Sediments of the peat bog provide information on the origin and vegetation evolution of this area.
\end{abstract}

Keywords: palaeogeoecology, radiocarbon dating, Holocene, Bohemian-Moravian Uplands, Czech Republic.

\section{INTRODUCTION}

Pollen analysis of peat bog complexes in the Českomoravská vrchovina (Bohemian-Moravian Uplands) provides a possibility of monitoring the development of vegetation during the Late Glacial and the Holocene period after recession of the last glaciation about 15,000 years ago. A review of the oldest palynological studies on this territory (Firbas 1927, Rudolph 1927, Salaschek 1935, Puchmajerová 1943, Kneblová-Vodičková 1961, 1966, 1970) allows to conclude that pollen analyses were

Corresponding author: E. Břízová

e-mail: eva.brizova@geology.cz being carried out almost since their introduction into geological research. Later palaeobotanical research was carried out for the southern part of the region by Rybníček (Rybníček and Rybníčková 1961, 1968, Rybníčková 1974, Rybníčková and Rybníček 1980) and Peichlová (1977). Palaeobotanical research in the Světelsko area was carried out by Jankovská (1971, 1990).

The current paper presents the results of research performed in the northern part of the Protected Landscape Area of Žd'árské vrchy Hills and Železné hory Mts (Fig. 1). The most integral palaeoecological results were obtained from the deepest part of Velké Dářko peat bog 


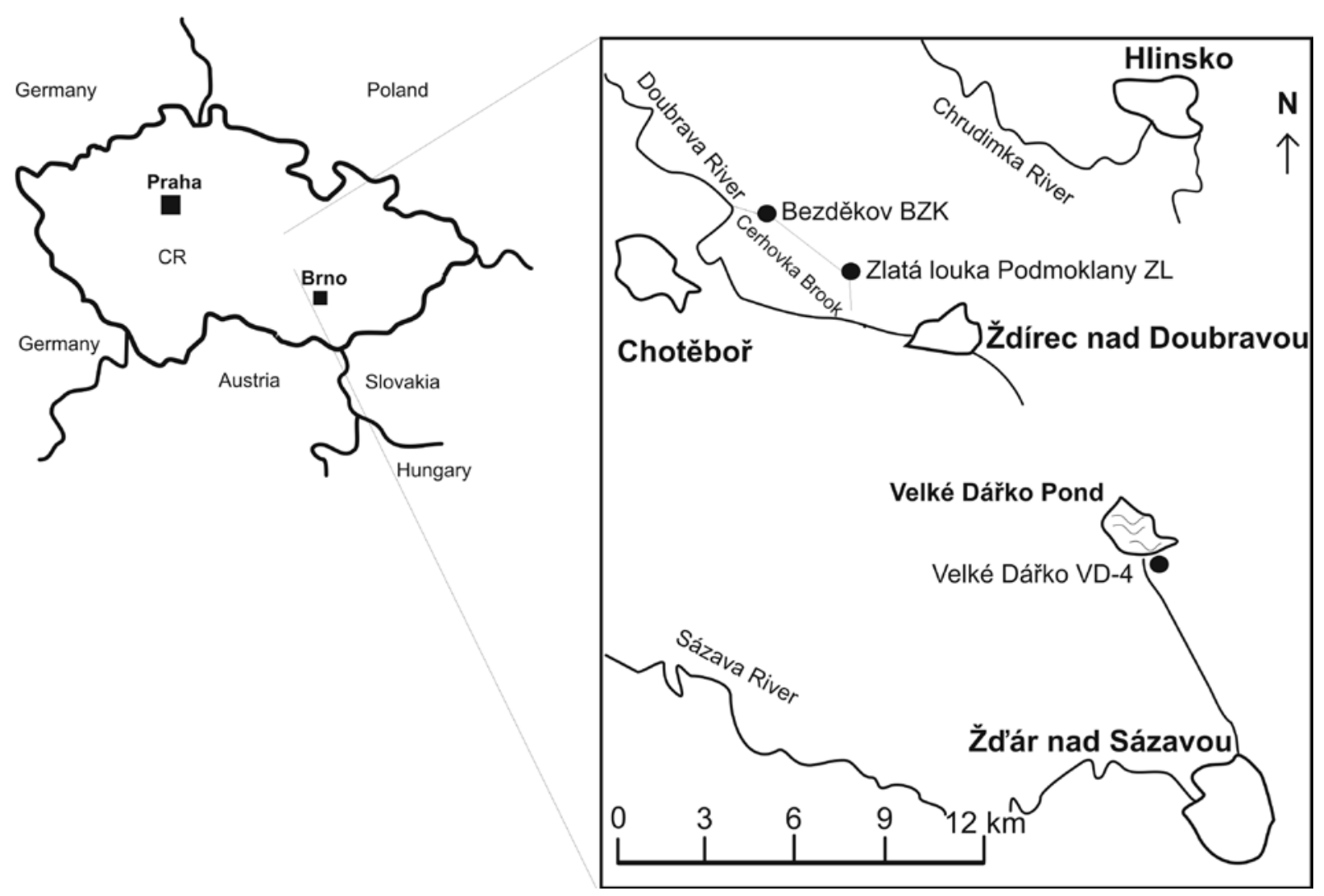

Fig. 1. Map of the area surrounding Bezděkov (BZK), Velké Dářko (VD-D4), Zlatá louka (ZL). BZK, VD-D4, ZL - localities (locations of profiles).

(8.25 to $8.6 \mathrm{~m}$, Krucemburk sheet of geological map, scale 1:25 000), transitional peat bog Zlatá louka meadow by Podmoklany $(2.00 \mathrm{~m}$, Chotěboř sheet of geological map, scale 1:25 000) and fens in the alluvial plain of the brook Cerhovka (locality Bezděkov, Chotěboř sheet, Figs. 2 and 3).

The geological mapping of Quaternary sediments of the Protected Landscape Area of Žd'árské vrchy Hills and Železné hory Mts and palynological research in the chosen localities provide important data on the Quaternary development of this territory. The results of pollen analyses extend the knowledge on the territory development and its state from the standpoint of environmental quality, dynamics of forest development and other vegetation cover. They also indirectly draw attention to water management importance of this area.

In the past a number of peat bogs were devastated by exploitation, for example, one of the most unique peat bog complexes of Zalíbené was entirely extracted (Kneblová-Vodičková 1961, 1966, 1970). Smaller wetlands were often affected by local exploitation or had to undergo technical works. In the past, peat was mainly used locally in gardening, for balneological purposes and probably for heating.

The Železné hory Mts were declared Protected Landscape Area only in 1991, but their height, area and importance cannot be compared with the Žd'árské vrchy
Hills. The geological basement originated in the PrePalaeozoic (quartzites, granites), the Mesozoic (sandy marls, marlstones), while the younger part of the territory has been developing until the present time. In the southern part, the mountains border with Cretaceous sediments of the so-called Long ridge. Inside the mountains, the landscape is divided by many valleys, river plains, rocky gorges and hills, forests and human settlements. The good state of preservation of the natural environment ranks it among unique objects in the Czech Republic.

For the reconstructions of the palaeogeographical and palaeoecological development of the territory the peat bogs are most important, situated roughly between towns of Hlinsko - Svratka - Nové Město na Moravě - Žd'ár nad Sázavou - Ždírec nad Doubravou. Altogether, there are about 135 wetlands which are classified as raised bogs, transitional peat bogs and fens. Besides the above listed wetlands, there are also peat bogs originated secondarily, for example, in places of discharged ponds, obviously as remnants of former fish farming. The largest complex of unique wetland biotopes is indisputably the Ranské mokřady (wetlands); they are a spring area of rivers Doubrava and Sázava. The Žd'árské vrchy Hills and their surroundings are a principal spring area of rivers Chrudimka, Svratka, Svitava and Oslava.

The geographical and geological situation of the Žd'árské vrchy Hills and the presence of peat bogs deter- 


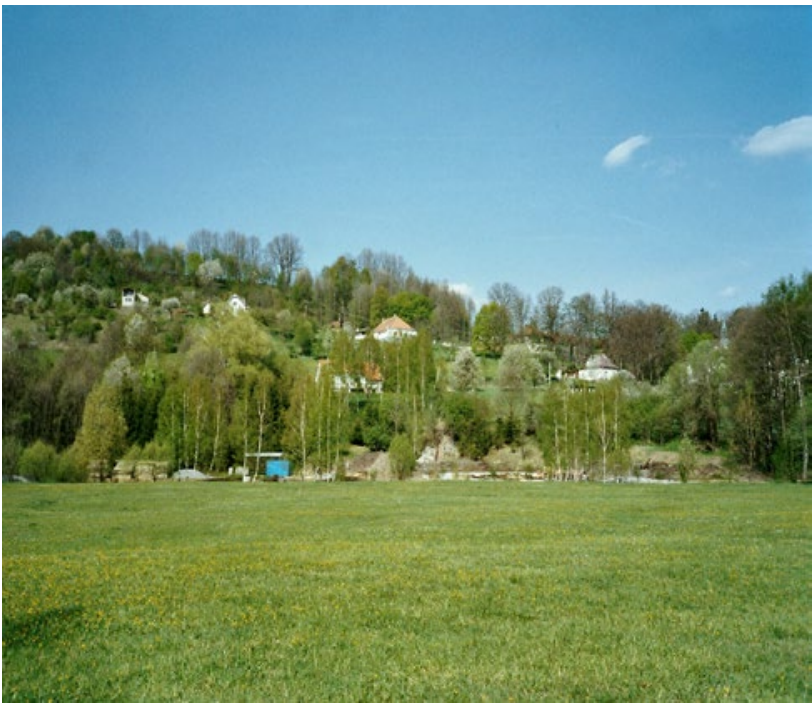

Fig. 2. The present state of the Bezděkov site.

mine their important location for water management (Břízová 2006a, 2006b). One of the main factors influencing the hydrological regime is a state of forest vegetation in the areas of upper streams and small inflows of big rivers. Disturbance of forest ecosystems and consequent disturbance of peat bogs function is cause in the area by aggressive interventions, wood exploitation and drainage of peat bogs. Activities like those might have prominent consequences such as floods on big rivers as it appeared in years 1997 and 2002. The development of vegetation conditions of peat bogs is influenced, except climate, by a range of factors, like sea level and geographical position, as well as the type of geological background (Břizová 2009a, 2009b). Peat soils have been deposited for millennia on impermeable basement of the crystalline rocks or Cretaceous sediments. Runoff conditions from the territory have fluctuated slightly which is caused by natural retention possibilities of landscape elements such as peat bogs, meandering streams, ponds and water reservoirs.

\section{METHODOLOGY}

Samples for pollen analysis were collected by handdrilled well or extracted directly from exposures. The laboratory preparation included one-day maceration in HF (Overbeck 1958) and acetolysis method described by Erdtman (1954). Maceration in HF enables to decompose inorganic particles (Faegri et al., 1964, Overbeck 1958), while acetolysis allows decomposition of cellulose and surplus organic remains that prevent good observation and calculation of palynological objects (pollen grains, spores, non-pollen microfossils). As a medium for microscopic biological samples a mixture of glycerine-ethanoldistilled water was used. 1-5 preparations of glass were

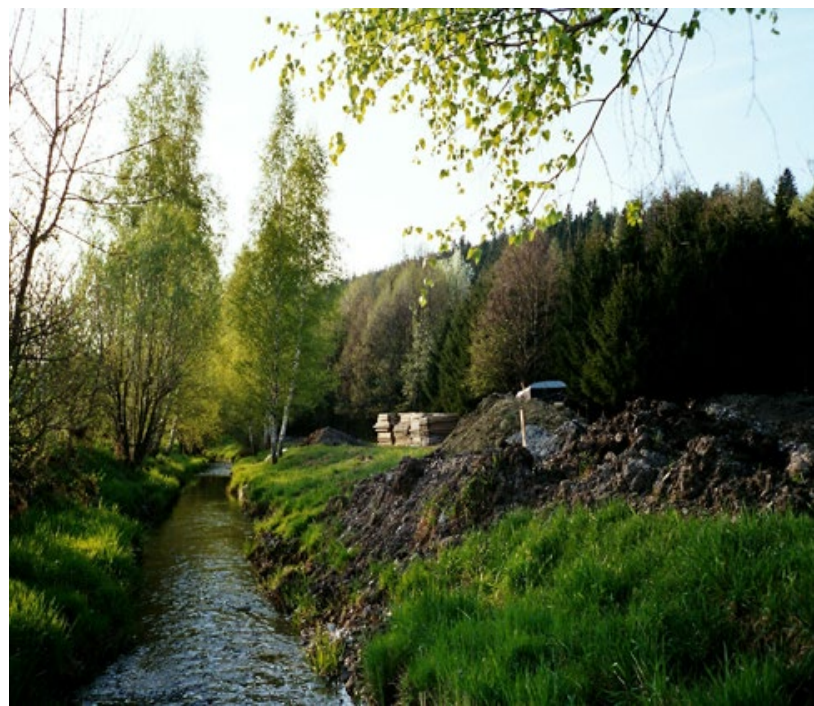

Fig. 3. The location of the Cerhovka Brook and the present state (see Fig. 2).

observed under the microscope, depending on sporomorph concentrations in a given sample.

Data obtained by microscopic analysis were evaluated in order to construct a pollen diagram, considering a sum of found pollen grains of wood species (AP) and herbaceous (NAP) to be $100 \%(\mathrm{AP}+\mathrm{NAP}=100 \%)$. The counted absolute values of pollen grains of different types of wood and herbs species were normalised to this sum to obtain relative values which were the basis for construction of pollen diagrams in the program POLPAL (Walanus and Nalepka 1999, Nalepka and Walanus 2003). Relative dating of pollen spectrum was carried out according to its composition. For the reconstruction of vegetation development the classification according to Firbas $(1949,1952)$ and Walanus and Nalepka (2010) was used. Taxonomic classification of found pollen grains and spores is according to Kubát et al., (2002) and Beug (2004).

Radiocarbon dating was carried out in the Gliwice Radiocarbon Laboratory at the Silesian University of Technology, Poland. Radiocarbon concentration determinations for the samples was performed with use of the radiometric technique as described by Pazdur et al., (2003). Before measurements, samples were pre-treated using an acid-alkali-acid washing sequence in order to remove any carbonates, humic and fulvic acids and bacterial $\mathrm{CO}_{2}$. The obtained results, i.e. conventional radiocarbon ages were calibrated in order to attain information about the calendar ages of samples. Calibration was undertaken using the IntCal09 calibration data (Reimer et al., 2009) and accompanied by age-depth modelling with the use of Bacon software, performed for 1-cm-thick slices (Blaauw and Christen, 2011). The results of measurements are provided in Table 1, and the age-depth model is presented in Fig. 4. 
Table 1. The results of radiocarbon dating of samples from Bezděkov BZK profile.

\begin{tabular}{|c|c|c|c|c|}
\hline \multirow{2}{*}{$\begin{array}{c}\begin{array}{c}\text { Sample name, } \\
\text { depth }\end{array} \\
\text { Bezdekov } 5 \\
0.10-0.15 \mathrm{~m}\end{array}$} & \multirow{2}{*}{$\frac{\text { Lab. no. }}{\text { Gd-15789 }}$} & \multirow{2}{*}{$\begin{array}{c}\begin{array}{c}\text { Age }^{14} \mathrm{C} \\
\text { (BP) }\end{array} \\
1210 \pm 60\end{array}$} & \multicolumn{2}{|c|}{$\begin{array}{c}\text { Calibrated age range } 95.4 \% \\
\text { cal BP }\end{array}$} \\
\hline & & & $1280-980$ & $95.4 \%$ \\
\hline $\begin{array}{l}\text { Bezdekov } 4 \\
0.30-0.35 \mathrm{~m}\end{array}$ & Gd-15788 & $1040 \pm 80$ & $1180-780$ & $95.4 \%$ \\
\hline $\begin{array}{l}\text { Bezdekov } 3 \\
0.65-0.70 \mathrm{~m}\end{array}$ & Gd-15798 & $1900 \pm 70$ & $\begin{array}{l}2010-1680 \\
1670-1620\end{array}$ & $\begin{array}{c}92.6 \% \\
2.8 \%\end{array}$ \\
\hline $\begin{array}{l}\text { Bezdekov } 2 \\
0.95-1.00 \mathrm{~m}\end{array}$ & Gd-12740 & $1955 \pm 55$ & $2050-1730$ & $95.4 \%$ \\
\hline $\begin{array}{l}\text { Bezdekov } 1 \\
1.05-1.10 \mathrm{~m}\end{array}$ & Gd-15787 & $2460 \pm 80$ & $2730-2350$ & $95.4 \%$ \\
\hline
\end{tabular}

\section{RESULTS}

\section{Lithology}

The sediment for the present study was collected from Bezděkov near Chotěboř, placed $420 \mathrm{~m}$ above the sea level (Fig. 1). It is a fen located on the plain of small river Cerhovka Brook. The depth of analysed sediments ranged from 0 to $1.10 \mathrm{~m}$ (Fig. 5).

Following lithological units have been distinguished:
a) $0-0.10 \mathrm{~m}$
flood loam, brown;
b) $0.10-0.33 \mathrm{~m}$ peat, dark brown;
c) $0.33-1.05 \mathrm{~m}$ clayey, grey-brown;
d) $1.05-1.10 \mathrm{~m}$ sand with trunks at the bottom.

\section{Dating}

The obtained age-depth model for investigated profile provides Maximum A posteriori Probability (MAP) estimates, which are modes of the posterior probability distribution of calendar age for a given depth, as well as maximum and minimum ages (see Fig. 4). The relatively high intervals of modelled ages have to be kept in mind, i.e. the average age interval for the probability of $95.4 \%$ is ca. $360 \mathrm{yrs}$.

\section{Pollen analysis and non-pollen microfossils}

The collected Bezděkov profile records ca. 1500 years of the vegetation development. Sedimentation of the Bezděkov fen profile started under more favourable conditions of the Older Subatlantic (2550 cal BP, see Tables 1, 2 and Appendix), when the Cerhovka floodplain was raised. A younger Holocene section (Upper Holocene) can be clearly distinguished on the pollen diagram (Figs. 6 and 8). Four Local Pollen Assemblage Zones (L PAZ: BZK1a, b, c-2) were distinguished in the pollen diagram made from a $1.10 \mathrm{~m}$ thick sediment profile from the Bezděkov fen:

a) BZK-1a-IX: Cyperaceae - Pinus - Picea (Older Subatlantic);

b) BZK-1b-IX: Alnus - Abies - Picea - Fagus - Anthropophyta (Older Subatlantic);

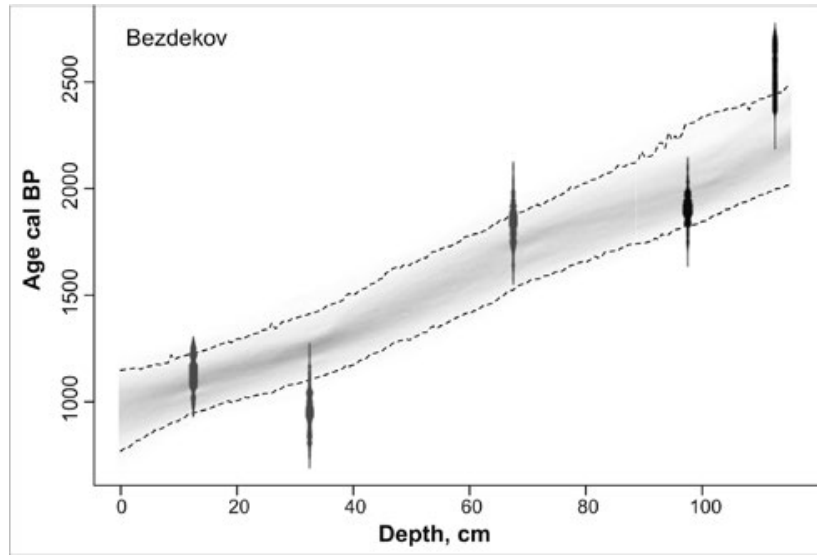

Fig. 4. Age-depth model for Bezděkov core based on radiocarbon dating, obtained with the use of Bacon software (Blaauw and Christen, 2011). The probability distributions of calendar age obtained for single samples are dark grey. Grey-shaded area represents the ranges of the model, while the darker grey colour is used for the higher probability.

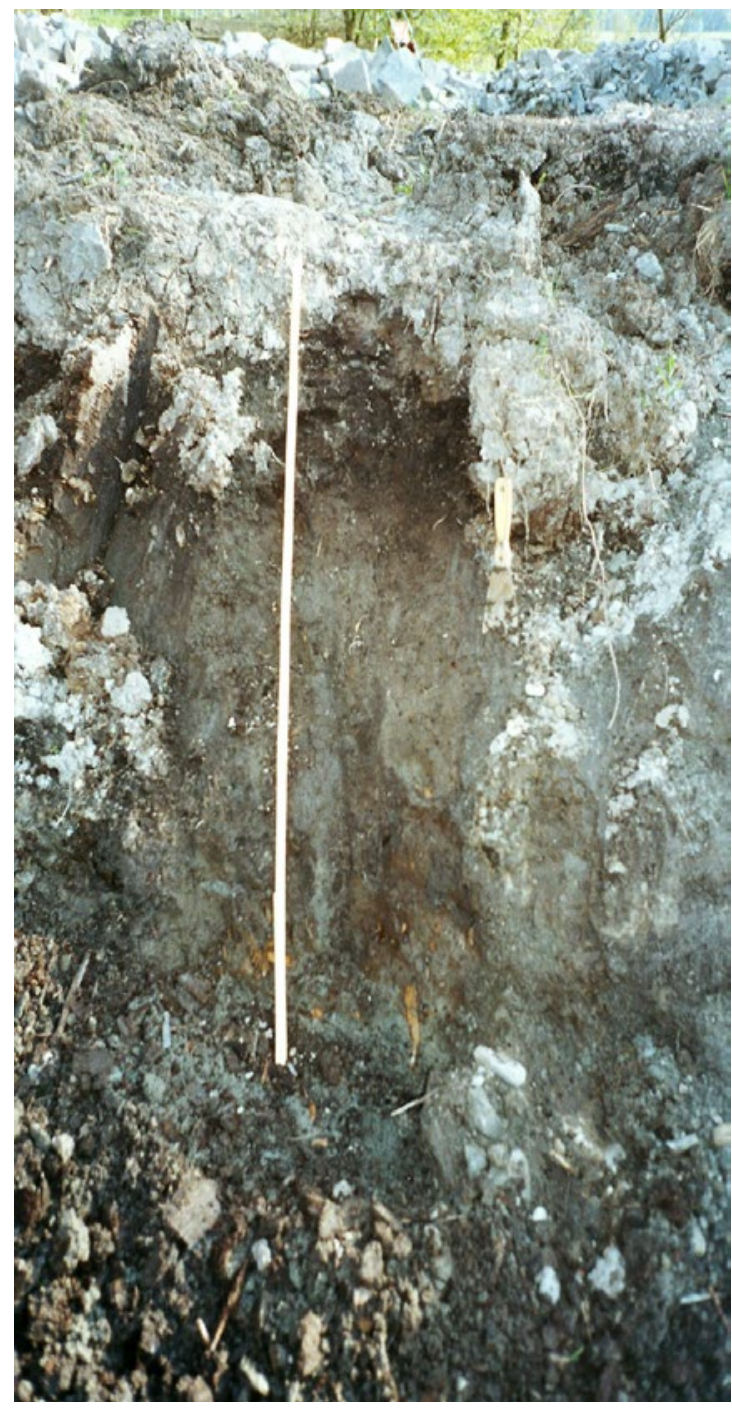

Fig. 5. The situation (location) of the Bezděkov profile (see Lithology). 


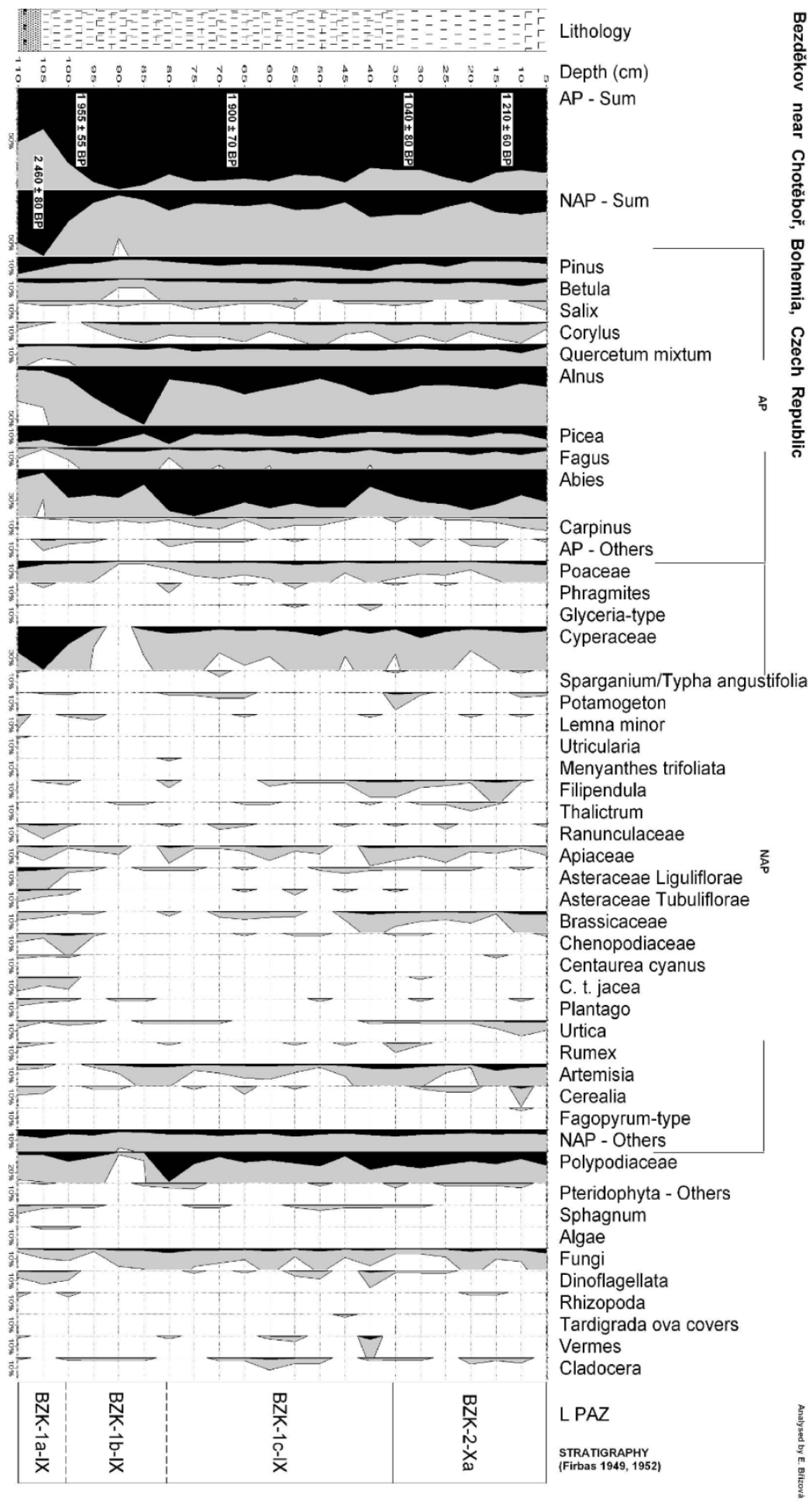

Fig. 6. Pollen diagram Bezděkov (BZK, 420 m a.s.I.) by Chotěboř, Bohemia, Czech Republic. Lithology: see Stratigraphical and lithological development of newly elaborated locality. Analysed by E. Brízová. 
E. Břízová et al.

Table 2. Stratigraphic table of Holocene periods used in text follows (according to Bř̆zová in Dreslerová et al., 2004, Mangerud et al., 1974, Walanus and Nalepka 2010).

\begin{tabular}{lcccc}
\hline Holocene & $\begin{array}{c}\text { Modified stratigraphy by } \\
\text { Bř́zová (Dreslerová et al., } \\
\text { 2004), }{ }^{14} \text { C BP }\end{array}$ & $\begin{array}{c}\text { Modified stratigraphy by } \\
\text { Břzizová (Dreslerová et al., } \\
\text { 2004), cal. BP }\end{array}$ & $\begin{array}{c}\text { Stratigraphy by Mangerud } \\
\text { et al., 1974, } \\
\text { 14C BP }\end{array}$ & $\begin{array}{c}\text { Modified stratigraphy by } \\
\text { Mangerud (Walanus and } \\
\text { Nalepka 2010), cal. BP }\end{array}$ \\
\hline Subatlantic IX, X & $2800-$ recent & $2900-$ recent & $2500-$ recent & $2550-$ recent \\
\hline Subboreal VIII & $5100 / 4500-2800$ & $5800 / 5150-2900$ & $5000-2500$ & $5750-2550$ \\
\hline Atlantic VI, VII & $7700-5100 / 4500$ & $8500-5800 / 5150$ & $8000-5000$ & $8950-5750$ \\
\hline Boreal V & $9100-7700$ & $10250-8500$ & $9000-8000$ & $10150-8950$ \\
\hline Preboreal IV & $10250-9100$ & $12000-10250$ & $10000-9000$ & $11450-10150$ \\
\hline
\end{tabular}

c) BZK-1c-IX: Abies - Alnus - Picea - Polypodiaceae - Vermes (Older Subatlantic);

d) BZK-2-Xa: Abies - Alnus - Anthropophyta (Older phase of the Younger Subatlantic).

The present results indicate that the Older Subatlantic (IX) phase is extensively developed on the locality of Bezděkov by Chotěboř (Figs. $\mathbf{6}$ and $\mathbf{8}$ ), with fir (Abies) as dominant specie (Fig. 7.1). Alder and floodplain forest was growing in the plain of the Cerhovka brook. The period is characterised by huge invasion of fir and development of beech-fir forests with addition of spruce and decline of Quercetum mixtum (QM, Fig. 7). Today's vegetation was formed in this time. In some areas the first traces of scarce settlement occur.

More permanent settlement occurs only in the following period of Younger Subatlantic (Xa, ca. 800 cal BP present, Břízová in Dreslerová et al., 2004). The original natural forests were very often cut down, burned out or changed to arable land and settlements. Forests were later artificially planted; the original woody species were replaced by quickly growing pine (Pinus) and spruce (Picea) with addition of birch (Betula). Human activity is represented in the diagrams by synanthropic plants and corn (Asteraceae, Brassicaceae, Artemisia, Cerealia, Fagopyrum). The development of this vegetation differs between individual localities.

The consequence of agricultural activities was the clearance of alder-dominated woodland. During the several millennium history of vegetation development, the woody species such as fir (Abies), small-leaved linden (Tilia cordata) and large-leaved linden (T. platyphyllos), beech (Fagus) have lost dominant importance. The spruce (Picea) has started to appear more vigorously, as it can be seen today on the majority of the area, which has probably been amplified by artificial planting that began mainly in the first half of the $19^{\text {th }}$ century. In $15^{\text {th }}$ and $16^{\text {th }}$ centuries ponds were built in the area, e.g. the Velké Dářko, which have been functioning up to now. For centuries the agriculture affected remaining forests which were used for pasture of beef cattle and sheep. Significant amounts of wood were consumed by ironworks and glassworks that used mainly beech (Fagus), which resulted in its considerable decline. Traces of mineral deposit extraction of silver, ironstones, coloured metals and peat can also be found.

Wetland plants such as species from families Cyperaceae and Ranunculaceae, Phragmites, Thalictrum, Filipendula, Glyceria-type, Sparganium/Typha angustifolia, Menyanthes trifoliata, the spores Sphagnum, Polypodiaceae and Polypodium vulgare indicate on the presence of swampy areas. The free water level was indicated by Utricularia, Potamogeton, Lemna minor, by algae (Botryococcus, Pediastrum) and by Cladocera (Fig. 7).

\section{DISCUSSION}

Pollen analyses and radiocarbon dating verified sediment age from the Older Subatlantic (IX) up to the older phase of Younger Subatlantic (Xa). Wetland has been created in the plain of Cerhovka brook and according to the research results, its age ranges cover only the Upper Holocene around 2500-3000 years (Bř́zová 2008a, 2008b). From the stratigraphical standpoint, sedimentary filling on the locality of Bohutín in the plain of small river Litavka has also the same character of development (Břízová 2008a). Significant occurrence of fir (Abies) in the period of the Older Subatlantic and the Older phase of Younger Subatlantic (Bezděkov) was confirmed also at palynological research of the Bohemian Paradise Geopark on the locality of Mříčná - Zimrov (end of Subboreal, Older Subatlantic and Older phase of Younger Subatlantic, Semily sheet of geological map, scale 1:25 000, Břizová, 2010). Therefore, the dominance of fir revealed at around 400-500 $\mathrm{m}$ above sea level was proven for the period, when man did not intervene so much in development of forest ecosystems in piedmont and mountainous areas.

Palaeoecological development of the BohemianMoravian Uplands territory can be compared with development of the border mountains of the Czech Republic (e.g. Mentlík et al., 2010). The specific local conditions are prominently different from the conditions for the area of southern Moravia, where several palaeolakes were discovered and examined, e.g. Vacenovice (Bř́zová 2006c), Čejčské Lake (Břízová 2009c), Pohansko (Doláková et al., 2010). 

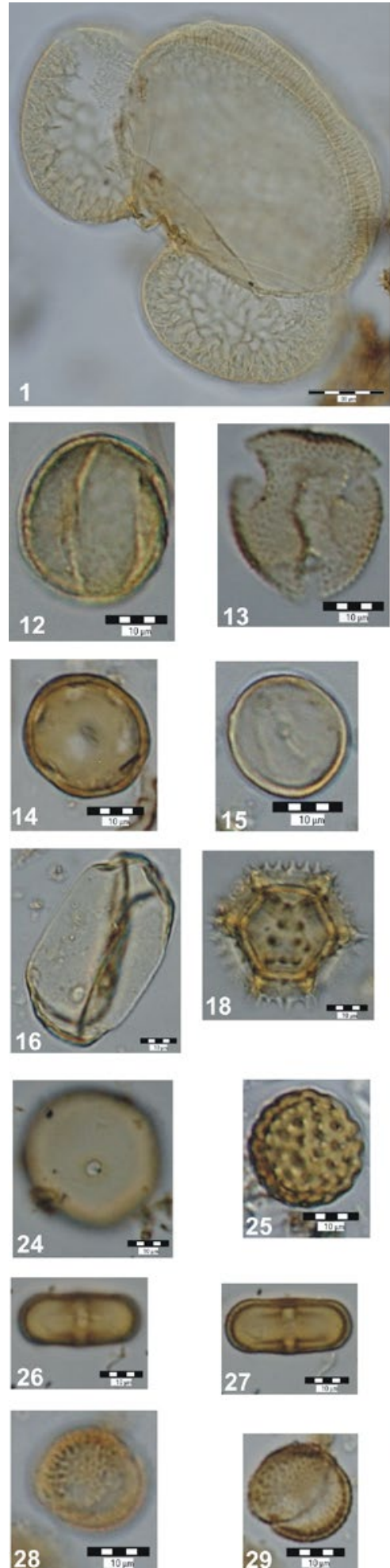
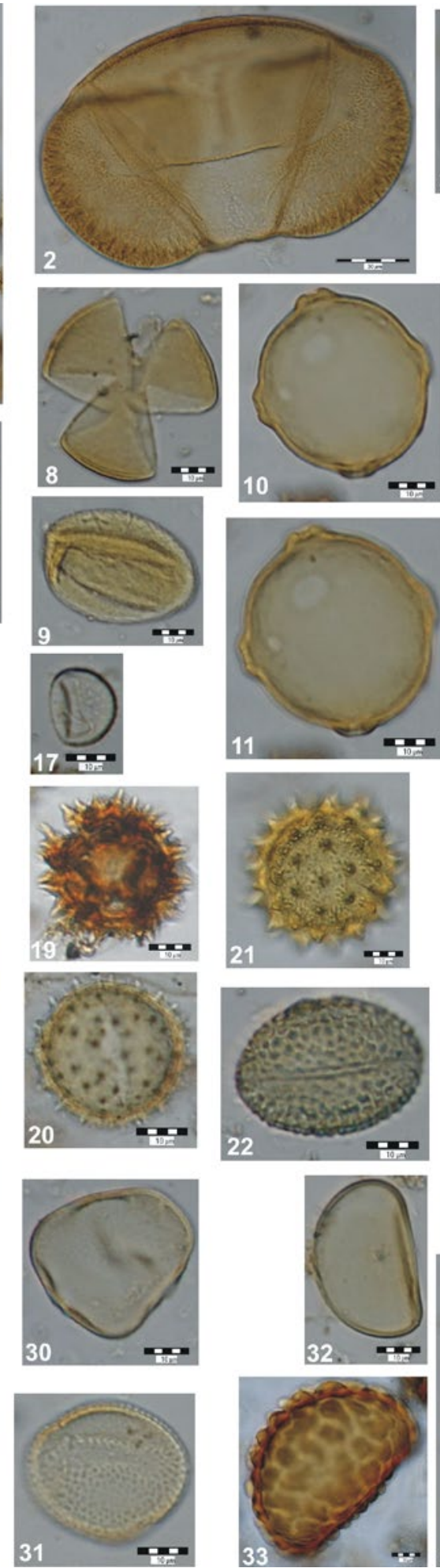
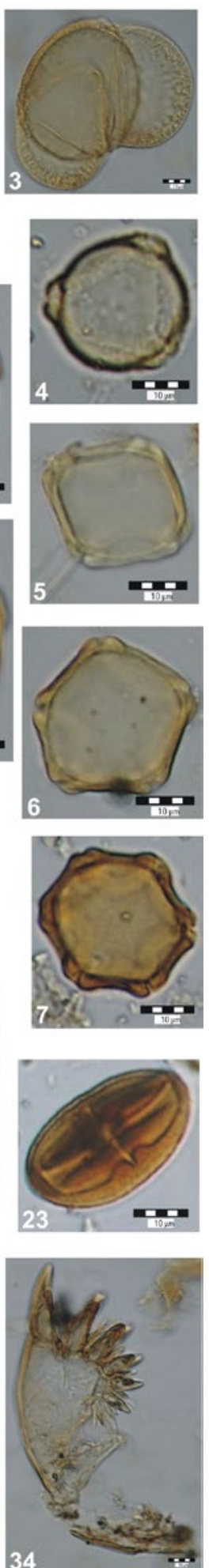

Fig. 7. Palynomorphs from the Bezděkov (BZK) profile AP: 1 - Abies, depth $0.05 \mathrm{~m}$; 2 - Picea, depth $0.05 \mathrm{~m}$; 3 - Pinus, depth $0.05 \mathrm{~m}$; 4-7 - Alnus, depth $0.35 \mathrm{~m}, 0.05 \mathrm{~m}, 0.15 \mathrm{~m}, 0.20 \mathrm{~m} ; 8,9$ - Acer, depth $0.10 \mathrm{~m}, 0.30 \mathrm{~m} ; 10,11$ - Carpinus, depth $0.05 \mathrm{~m} ; 12$ - Quercus, depth $0.80 \mathrm{~m} ; 13$ - Fraxinus, depth 0.10 m. NAP: 14 - Thalictrum, depth 0.20 m; 15 - Urtica, depth 0.20 m; 16 - Cerealia T. Secale, depth 0.65 m; 17 - Lemna cf. minor, depth $0.10 \mathrm{~m} ; 18,19$ - Asteraceae Liguliflorae, depth $0.30 \mathrm{~m}, 0.25 \mathrm{~m} ; 20$ - Astraceae Tubuliflorae, depth $1.10 \mathrm{~m}$; 21 - Carduus/Cirsium, depth 0.80 m; 22 - Fagopyrum, depth 0.10 m; 23 - Centaurea cyanus, depth 0.15 m; 24 - Poaceae, depth 0.05 m; 25 - Chenopodiaceae, depth 0.35 m; 26, 27 - Apiaceae, depth $0.05 \mathrm{~m}$; 28, 29 - Brassicaceae, depth $0.05 \mathrm{~m} ; 30$ - Cyperaceae, depth $0.05 \mathrm{~m} ; 31$ - Sparganium/Typha angustifolia, depth $0.10 \mathrm{~m}$. Spores: 32 - Polypodiaceae, depth $0.05 \mathrm{~m}$; 33 - Polypodium vulgare, depth $0.15 \mathrm{~m}$. Other microfossils: 34 - Cladocera, depth $0.10 \mathrm{~m}$. Scale $30 \mu m$ (1, 2), $10 \mu m$ (3-34). Photo E. Brízová. 
Pollen analyses carried out so far for the area of Bohemian-Moravian Uplands revealed satisfactory state of the current forest ecosystems (Bř́zová 2006a, 2006b, 2006c, 2009a, 2009b) against, for example, the Krušné hory Mts (Jankovská et al., 2007, Vile et al., 1995) and other territories (Jankovská 2006, 2007, Novák et al., 2008).

The Older Subatlantic (IX, ca. 2900-800 cal BP, Břízová in Dreslerová et al., 2004) was identified in all pollen diagrams of the Bohemian-Moravian Uplands at Velké Dářko and Zlatá louka (Břízová 2006b), except Zalíbené site, where the upper part of sediment was removed before sampling for pollen analysis (KneblováVodičková 1961, 1966, 1970).

The herb taxa are again represented by anthropogenic indicators and by cereals (Cerealia T. Secale, T. Triticum). Mainly the types of family Polypodiaceae and the destroyers of organic matter such as Ascomycetes were found among the spores together with lesser amounts of Arcella, Hyalosphenia subflava (Rhizopoda).

More varied weed types and anthropogenic indicators such as Centaurea cyanus, as well as plants typical for medieval settlements, for example Fagopyrum, occurred on a larger scale. Intestinal parasites of humans and pigs such as Ascaris cf. lumbricoides, Trichuris cf. trichiura (BZK-1c-IX) were also recorded in this period, similarly to the medieval Prague, Budeč and in other medieval towns (Břízová 1997, 1998, Břízová and Bartošková 1994).

\section{CONCLUSIONS}

Pollen and non-pollen microfossils have been successfully used in this study for the precise reconstruction of local palaeoenvironments demonstrating new possibilities for the interpretation of palynological assemblages. It is especially important for the understanding of regional and local environmental trends in swampy regions of the Protected Landscape Areas Žd'árské vrchy Hills and Železné hory Mts. Such reconstructions are important in the vicinity of the Bohemian-Moravian Uplands. Moreover, they provide a basis for the prediction of the future changes there, which is especially important for the floodplain areas of Bohemia, where anthropogenic influence has strongly increased during recent decades.

Pollen analysis has been carried out on a $1.10 \mathrm{~m}$ thick sediment profile from the locality Bezděkov ( $420 \mathrm{~m}$ a.s.l.) near Chotěboř (Figs. 1, 2 and 3) in the Protected Landscape Area Železné hory Mts (Czech Republic). Analyses of 22 samples characterise the development of the wetland biotope and the surrounding landscape during the time interval from 2550 to $800 \mathrm{cal} \mathrm{BP}$. The pollen diagram shows a transition between the Upper Holocene biostratigraphic units at a depth of $0.33 \mathrm{~m}$ (ca. 1180-780 cal BP, see Table 1). Alnus and Abies were the dominant trees during all the time.
The Cerhovka Brook was an important factor in the development of the vegetation cover in the vicinity of wetland in the Upper Holocene. Palynological study of the organic sediments of the Cerhovka revealed the complexity of the vegetation history of this small floodplain. Instability of the mostly inorganic sediments has been proved by the redeposition of Cretaceous sporomorphs and by Dinoflagellata presence (see pollen diagram in the Fig. 6). The brook banks were covered by alderdominated woodland with local formations of native grassland with herb-dominated photophilous vegetation and wetland vegetation.

Human impact on the natural ecosystem has been recorded since the beginning of the second half of the Older Subatlantic (ca. 1800 cal BP). It was first marked by pasture then by crop cultivation towards the end of the period.

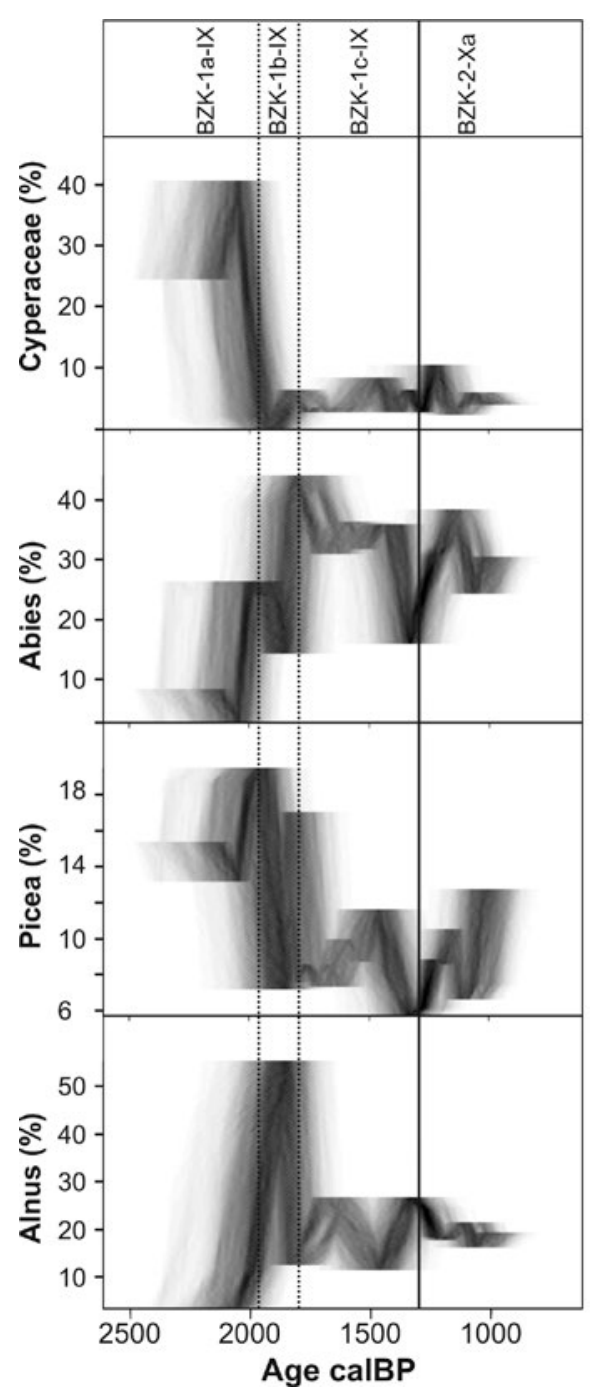

Fig. 8. Changes of the relative abundance of selected representative pollen taxa on the absolute age scale. Grey-shaded area represents the uncertainty of the age-depth model (see Fig. 4). Plots prepared with use of Bacon software (Blaauw and Christen, 2011). 


\section{ACKNOWLEDGMENTS}

The research stated in the submitted work are compared with results of many years study of the above mentioned paleobotanists (Rudolph, Firbas, Salaschek, Puchmajerová, Kneblová-Vodičková, Rybníček, Rybníčková, Jankovská, Peichlová), whom I thank very much to for the written heritage and valuable remarks to the work on the territory of the Bohemian-Moravian Uplands. The author continued in dealing with this problems during the geological mapping of the Protected Landscape Area of Žd'árské vrchy Hills on scale of 1:25 000 within the research aim of MZP 0002579801 and within the research aim of MZP Global climatic changes, in the grant project of GA CR (Novák et al., 2006-2008: Isotope composition of carbon forms in peat bogs in relation to climatic changes) and internal project of CGS Prague $(332600,326500)$.

\section{APPENDIX}

The table with real amount of pollen grains and spores in individual samples from the locality of Bezděkov BZK is available in electronic version of this article at http://dx.doi.org/10.2478/s13386-012-0016-2 as Supplementary Material.

\section{REFERENCES}

Beug HJ, 2004. Leitfaden der Pollenbestimmung für Mitteleuropa und angrenzende Gebiete (Guide of the pollen classification for Central Europe and adjacent areas). Verlag Dr. Friedrich Pfeil, München: 542pp (in German).

Blaauw M and Christen JA, 2011. Flexible paleoclimate age-depth models using an autoregressive gamma process. Applied Statistics 6: 457-474, DOI 10.1214/11-BA618.

Břízová E, 1997. Rekonstrukce životního prostředí ve středověké Praze (Reconstruction of the environment in medieval Prague). Zprávyo geologických výzkumech v roce 1996: 161-162. Praha (in Czech).

Břízová E, 1998. Pylová analýza sedimentu středověké Sněmovní ulice v Praze (Prague medieval Sněmovní street - pollen analysis of its sediments). Archaeologica Pragensia 14: 317-328. Praha.

Bř́zová E, 2006a. Findings of the organic sediments investigation at the geological mapping in the Protected Landscape Area Žd'árské vrchy. In Smolová I, ed., Geomorfologické výzkumy v roce 2006: 22-25. Olomouc.

Bř́zová E, 2006b. Zlatá louka peat bog - the source of the climatic date from Late Glacial to Recent. Scripta Facultatis Scienciarum Naturalium Universitatis Masarykianae Brunensis, Geology 33-34: 1921.

Bř́zová E, 2006c. Palaeoalgology and palynology of the Vacenovice Lake. Acta Universitatis Carolina, Geologica 47(1-4) 41-42.

Bř́zová E, 2008a. Reconstruction of vegetation development on the floodplain of the Litavka River in the Holocene (Central Bohemia, Brdy Mts.). Acta Musei Nationalis Prague, Ser. B. Historia Naturalis $64(2-4): 173-184$.

Břízová E, 2008b. Paleoekologický vývoj niv během pozdního glaciálu a holocénu ve střední Evropě (Palaeoecological development of floodplains during Late Glacial and Holocene in Central Europe). In Pithart $\mathrm{D}$, Benedová $\mathrm{Z}$ and Křováková $\mathrm{K}$, eds., Ekosystémové služby ř́čni nivy (Ecosystem survey of floodplain). Ústav systémové biologie a ekologie AV ČR, v.v.i., Vodní hospodárství. Třeboň: 11-19 (in Czech).
Břízová E, 2009a. Dynamika vývoje lesní vegetace na Českomoravské vrchovině z pohledu palynologie (Dynamic of forest vegetation in the Bohemian-Moravian Uplands from a palynological point of view). Zprávy České botanické společnosti 44, Mater. 24: 45-58.

Bř́zová E, 2009b. Use of organic sediments of Velke Darko to study climatic changes during 15,000 years (Protected Landscape Zdarske vrchy, Czech Republic). In Ukonmaanaho L, Nieminen TM andStarr M, eds., 6th International Symposium on Ecosystem Behaviour BIOGEOMON 2009. Working Papers of the Finnish Forest Research Institute 128: 484. Helsinki.

Bř́zová E, 2009c. Quaternary environmental history of the Čejčské Lake (S. Moravia, Czech Republic). Bulletin of Geosciences 84(4): 637-652, DOI 10.3140/bull.geosci.1140.

Břízová E, 2010. Nové poznatky o kvartérních organických sedimentech na území Geoparku Český ráj (New data on Quaternary organic sediments on the territory of the Bohemian Paradise Geopark). Zprávy o geologických výzkumech v roce 2009: 87-96 (in Czech).

Bř́zová E and Bartošková A, 1994. Early medieval hillfort of Budeč: reconstruction of environment of the basis of pollen analysis. Sborník geologických věd. Antropozoikum 21: 75-86.

Doláková N, Roszková A and Přichystal A, 2010. Palynology and natural environment in the Pannonian to Holocene sediments of the Early Medieval centre Pohansko near Břeclav (Czech Republic). Journal of Archaeological Science 37(10): 2538-2550, DOI 10.1016/j.jas.2010.05.014.

Dreslerová D, Břízová E, Růžičková E and Zeman A, 2004. Holocene environmental processes and alluvial archaeology in the middle Labe (Elbe) valley. In Gojda M, ed., Ancient landscape, settlement dynamics and non-destructive archaeology, Academia, Praha: 121-171.

Erdtman G, 1954. An introduction to pollen analysis. Waltham (USA): 239pp.

Faegri K Iversen I and Waterbolk H,et al., 1964. Textbook of pollen analysis. Copenhagen: 237pp.

Firbas F, 1927. Paläofloristische und stratigraphische Untersuchungen böhmischer Moore IV. Die Geschichte der nordböhmischen Wälder und Moore seit der letzten Eiszeit. (Untersuchungen in Polzengebiet). Beihefte zum Botanisches Centralblatt XLIII: 145219. (in German).

Firbas F, 1949, 1952. Spät- und nacheiszeitliche Waldgeschichte Mitteleuropas nördlich der Alpen. I. Allgemeine Waldgeschichte. II. Waldgeschichte der einzelnen Landschaften. Jena (Fischer): 480 pp, 256 pp (in German).

Jankovská V, 1971. The development of vegetation on the western slopes of the Bohemian-Moravian Uplands during the Late Glacial and Holocene Period: A study based on pollen and macroscopic analyses. Folia Geobotanica et Phytotaxonomica 6: 281-302. Praha.

Jankovská V, 1990. The evolution of Late-Glacial and Holocene Vegetation in the vicinity of Světlá nad Sázavou (in the western forland of the Bohemian-Moravian Uplands). Folia Geobotanica et Phytotaxonomica 25: 1-25. Praha.

Jankovská V, 2006. Late Glacial and Holocene history of Plešné Lake and its surrounding landscape based on pollen and palaeoalgological analyses. Bratislava. Biologia 61(20): 371-385.

Jankovská V, 2007. Giant Mountains and pollenanalytical research: New results and interesting palaeobotanical findings. In: Štursa J and Knapik R, eds., Geoekologické problémy Krkonoš. Sborn. Mez. Věd. Konf., říjen 2006, Svoboda n. Úpou. Opera Corcontica 44(1): 227-242

Jankovská V, Kuneš P and van der Knaap WO, 2007. 1. Fláje-Kiefern (Krušné Hory Mountains): Late Glacial and Holocene vegetation development. Grana 46(3): 214-216, DOI 10.1080/00173130701526341.

Kneblová-Vodičková V, 1961. Pozdní glaciál v rašeliništi v Zalíbeném (Late Glacial in Zalíbené peatbog). Věstník ÚÚG, XXXVI: 445 (in Czech).

Kneblová-Vodičková V, 1966. Das Spätglazial im Moor bei Zalíbené in Ostböhmen (Late Glacial in Zalíbené peatbog in East Bohemia). Preslia 38: 154-162 (in German). 
Kneblová-Vodičková V, 1970. Das Spätglazial im Moor bei Zalíbené in Ostböhmen (Late Glacial in Zalíbené peatbog in East Bohemia). Preslia 42: 377-378 (in German).

Kubát K, Hrouda L, Chrtek J jun, Kaplan Z, Kirschner J and Štěpánek J, eds., 2002. Klič ke květeně Čské republiky (Key to flora of the Czech Republic). Academia Praha: 928pp (in Czech).

Mangerud J, Andersen ST, Berglund BE and Conner JJ, 1974. Quaternary stratigraphy of Norden, a propsal for terminology and classification. Boreas 3(3): 109-128, DOI 10.1111/j.15023885.1974.tb00669.x.

Mentlík P, Minár J, Břízová E, Lisá L, Tábořík P and Stacke V, 2010. Glaciation in the surrounding of Práśilské Lake (Bohemian Forest, Czech Republic). Geomorphology 117(1-2): 181-194, DOI 10.1016/j.geomorph.2009.12.001.

Nalepka D and Walanus A, 2003. Data processing in pollen analysis. Acta Palaeobotanica 43(1): 125.

Novák M, Břízová E, Adamová M, Erbanová L and Bottrell SH, 2008. Accumulation of organic carbon over the past 150 years in five freshwater peatlands in western and central Europe. Science of the Total Environment 390(2-3): 425-436, DOI 10.1016/j.scitotenv.2007.10.011.

Overbeck F, 1958. Pollenanalyse quartärer Bildungen. In: Freund H, ed., Handbuch der Mikroskopie in der Technik. Frankfurt/Main: 325-410.

Pazdur A, Fogtman M, Michczyński A and Pawlyta J, 2003. Precision of ${ }^{14} \mathrm{C}$ dating in Gliwice Radiocarbon Laboratory. FIRI Programme. Geochronometria 22: 27-40.

Peichlová M, 1977. Paleogeobotanický výzkum mladoholocénního profilu u Rváčova (východní Čechy) (Paleogeobotanical research mid-holocene profile near Rváčov. East Bohemia). Preslia 49: 6790 (in Czech).

Puchmajerová M, 1943. Rašeliniště v oblasti Žd'árských vrchů na Českomoravské vysočině (Peatbogs in Žd'árské vrchy Hills Area in the Bohemian-Moravian Uplands). Zemédèlský archiv, $X X X I V / 6,1-20$. Praha (in Czech).
Reimer PJ, Baillie MGL, Bard E, Bayliss A, Beck JW, Blackwell PG, Bronk Ramsey C, Buck CE, Burr GS, Edwards RL, Friedrich M, Grootes PM, Guilderson TP, Hajdas I, Heaton TJ, Hogg AG, Hughen KA, Kaiser KF, Kromer B, McCormac FG, Manning SW, Reimer RW, Richards DA, Southon JR, Talamo S, Turney CSM, van der Plicht J, 2009. IntCal09 and Marine09 Radiocarbon Age Calibration Curves, 0-50,000 Years cal BP. Radiocarbon 51(4): 1111-1150.

Rudolph K, 1927. Profil radostínského rašelinového ložiska u rybníka Velké Dářko. ČNM (in Czech).

Rybníček K and Rybníčková E, 1961. Rašeliniště Jihlavských vrchů (Peatbogs in the Jihlavské vrchy Hills). Ochrana prírody 16(3): 78-84 (in Czech).

Rybníček K and Rybníčková E, 1968. The history of flora and vegetation on the Bláto mire in southeastern Bohemia, Czechoslovakia (Palaeoecological study). Folia Geobotanica et Phytotaxonomica 3: $117-142$.

Rybníčková E, 1974. Die Entwicklung der Vegetation und Flora im südlichen Teil der Böhmisch-Mährischen Höhe während des Spätglazials und Holozäns. Vegetace CSSR A7. Academia Praha.

Rybníčková E and Rybníček K, 1980. Holocene palaeovegetation and palaeoenvironment of the Kameničská kotlina Basin (Czechoslovakia). Folia Geobotanica et Phytotaxonomica 23: 285-301.

Salaschek H, 1935. Paläofloristische Untersuchungen mährischschlesischer Moore. Beihefte zum Botanisches Centralblatt Bd. $\mathrm{XIV} /$ Abt. B (in German).

Vile MA, Novák MJV, Bř́zová E, Wieder RK and Schell WR, 1995. Historical rates of atmospheric metal deposition using ${ }^{210} \mathrm{~Pb}$ dates Sphagnum peat cores: corroboration, computation, and interpretation. Water, Air and Soil Pollution 79(1-4): 89-106, DOI 10.1007/BF01100432.

Walanus A and Nalepka D, 1999. POLPAL. Program for counting pollen grains, diagrams plotting and numerical analysis. Acta Palaeobotanica Suppl. 2: 659-661.

Walanus A and Nalepka D, 2010. Calibration of Mangerud's boundaries. Radiocarbon 52(4): 1639-1644. 